\title{
Nutrient Sources and Harvest Frequencies Impact Water Stable Soil Macro-Aggregates
}

\section{Authors: Yesuf Assen Mohammed, and Kefyalew Girma Desta}

This is an Accepted Manuscript of an article published in Communications in Soil Science and Plant Analysis on December 5, 2017, available online:

http://www.tandfonline.com/10.1080/00103624.2017.1411514

Mohammed, Yesuf Assen , and Kefyalew Girma Desta. "Nutrient Sources and Harvest Frequencies Impact Water Stable Soil Macro-Aggregates." Communications in Soil Science and Plant Analysis 48, no. 19 (December 2017): 2359-2367. DOI: 10.1080/00103624.2017.1411514.

Made available through Montana State University's $\underline{\text { ScholarWorks }}$ scholarworks.montana.edu 


\title{
Nutrient Sources and Harvest Frequencies Impact Water Stable Soil Macro-Aggregates
}

\author{
Yesuf Assen Mohammed and Kefyalew Girma Desta ${ }^{b}$ \\ aEastern Agricultural Research Center, Montana State University, Sidney, MT, USA; ${ }^{b}$ Northern Agricultural Research \\ Center, Montana State University, Havre, MT, USA
}

\begin{abstract}
We evaluated the effects of nutrient sources [cattle manure, poultry litter, urea, chemical fertilizers [nitrogen $(\mathrm{N})$, phosphorus $(\mathrm{P})$ and potassium $(\mathrm{K})$ ], inter-seeded crimson clover (Trifolium incarnatum L.), and a control], and harvest frequency (single and twice) on water stable soil macro-aggregates through wet sieving. The experiment was performed in a split-plot design with four replications. In most cases, single harvest resulted in more water stable soil aggregates than twice harvest. This could be due to less soil disturbance and uninterrupted root exudate supplies for soil microbes. Application of cattle manure and poultry litter significantly increased the percent of water stable soil macro-aggregates to the extent of $47 \% \mathrm{com}$ pared with chemical (NPK) fertilizer application. These results demonstrated that vigilant recycling of these animal wastes could improve soil aggregate formation. However, long-term monitoring of this practice is needed to evaluate system sustainability and profitability.
\end{abstract}

\section{Introduction}

Confined animal farming operation involves raising large numbers of cows and birds in confinement. It is an important economic sector producing significant amount of revenue (Britton and Bullard, 1998; Payne and Zhang 2011). But it generates huge amounts of wastes over a limited geographic area causing water pollution challenging the sustainability of this important sector (Moore and Edwards 2005). Therefore, proper management of these wastes is needed to minimize negative environmental consequences.

In our previous publications, we showed that application of cattle manure (CM) and poultry litter (PL) increased switchgrass biomass yield for cellulosic feedstock and animal feed (Mohammed and Desta 2017; Mohammed et al. 2015). Several research results also showed a dramatic increase in biomass yield of switchgrass when soil nutrient levels are adequate or supplied as fertilizers (Lee, Owens, and Doolittle 2007; Muir et al. 2001; Sanderson, Read, and Reed 1999; Stout, Jung, and Shaffer 1988). Lee, Owens, and Doolittle (2007) reported that switchgrass biomass increased by $64.7 \%$ over the control with application of manure. However, information on the effect of CM and PL on soil macro-aggregate formation and stability is limited.

Soil aggregate stability is the ability of the soil to resist disturbance when there is stress (Amezketa 1999). It enhances the ability of the soil to withstand erosion and increase infiltration and water storage in the soil with overall improvement in system productivity. Soil aggregates are typically grouped into macro-aggregates $(>0.25 \mathrm{~mm})$ and micro-aggregates $(<0.25 \mathrm{~mm})$ based on their water stable aggregate sizes (Six et al. 2000; Tisdall and Oades 1982). Agronomic management practices influence the formation of soil macro-aggregates. The presence of stable soil aggregates and 
continuous pores in the soil are important soil quality that could enhance water infiltration, aeration, and root movement in the soil. This will improve water availability and potentially minimize surface runoff, eutrophication, and dam sedimentation. Several research results indicated that application of $\mathrm{N}$ fertilizer and manure improves the formation of soil macro-aggregates (Bronick and Lal 2005; Seybold and Herrick 2001; Tisdall and Oades 1980 ; Wei et al. 2006). But Jung et al. (2011) reported contradictory result showing reduced aggregate formation with increased $\mathrm{N}$ fertilization.

Application of CM and PL to switchgrass fields can serve as carbon and nitrogen sources for soil microbes besides providing nutrients to switchgrass. This will contribute to increased microbial diversity and activity in the soil ecosystem (Bot and Benites 2005; Kim et al. 2014; Zhen et al. 2014). In the process of mineralization of applied CM and PL, several organic compounds could be produced and serve as cementing agent ultimately contributing to the formation of stable soil aggregates. But this effect varies from locations to locations (Miller and Jastrow 1990; Tisdall and Oades 1982).

Some research result indicated that twice harvesting of switchgrass in a year increased cumulative biomass yield (Thomason et al. 2005). However, the effect of twice harvesting on soil aggregate stability is limited. Twice harvesting of switchgrass in a year may leave behind little residue in the soil to build organic matter causing nutrient depletion. This nutrient depletion together with increased compaction from the machinery due to increased frequency of harvesting could influence the formation of water stable soil aggregates.

The interaction effect of harvest frequency and application of different nutrient sources on water stable soil macro-aggregate in switchgrass field is less studied. We hypothesized that application of $\mathrm{CM}$ and PL and reduced harvest frequency will contribute to the formation of water stable soil macro-aggregates compared with chemical fertilizers application and increased harvesting frequency. Therefore, the objective of this study was to evaluate the effect of nutrient sources and switchgrass harvest frequency on water stable soil macro-aggregates.

\section{Materials and methods}

\section{Experimental sites}

The experiment was started in 2010 at Lake Carl Blackwell (LCB) $\left(36^{\circ} 08^{\prime} \mathrm{N} 97^{\circ} 17^{\prime} \mathrm{W}\right)$ and in 2009 at Perkins $\left(35^{\circ} 99^{\prime} \mathrm{N}\right.$ and $\left.97^{\circ} 04^{\prime} \mathrm{W}\right)$, Oklahoma State University experimental sites. The soil at LCB is a Pulaski (coarse-loamy, mixed, superactive, nonacid, thermic Udic Ustifluvents) fine sandy loam with $23 \mathrm{~g}$ organic matter $\mathrm{kg}^{-1}$ soil, $200 \mathrm{~g}$ clay $\mathrm{kg}^{-1}$ soil with $\mathrm{pH}$ of 5.7 . The long-term mean annual precipitation is $930 \mathrm{~mm}$ with an average daily high temperature of $31.6^{\circ} \mathrm{C}$ in the summer and an average daily low of $-4.8^{\circ} \mathrm{C}$ in the winter. The soil at Perkins consists primarily of Teller (fine-loamy, mixed, active, thermic Udic Argiustolls) loams and sandy loams. This soil has $13 \mathrm{~g}$ organic matter $\mathrm{kg}^{-1}$ soil and $60 \mathrm{~g}$ clay $\mathrm{kg}^{-1}$ soil with $\mathrm{pH}$ of 7.3. The long-term mean annual precipitation at Perkins is $926 \mathrm{~mm}$ with an average daily high temperature of $32.8^{\circ} \mathrm{C}$ in the summer and an average daily low of $-3.3^{\circ} \mathrm{C}$ in the winter.

\section{Experimental design and treatment}

The study was carried out in one-year-old established switchgrass (variety Alamo) field planted at seed rate of $6 \mathrm{~kg} \mathrm{ha}^{-1}$ pure live seed. Switchgrass was drilled into a well-prepared seedbed with a conventional drill (3P606NT, Great Plains, KS) at $1.5 \mathrm{~cm}$ soil depth and $36 \mathrm{~cm}$ wide rows in 2008 at Perkins and in 2009 at LCB. The design of the experiment was split plot with four replications. The size of the main plot was $6.1 \mathrm{~m}$ by $4.6 \mathrm{~m}$, and the sub-plot size was $1.52 \mathrm{~m}$ by $1.52 \mathrm{~m}$. The main plot treatments were harvest frequencies: (1) single harvest in November, (2) twice harvest one in June and one in November. The subplot treatments were nutrient sources: (1) cattle manure (CM), (2) poultry litter (PL), (3) Inter-seeded Crimson clover (Trifolium incarnatum L.), 
(4) urea at $150 \mathrm{~kg}$ nitrogen $\mathrm{ha}^{-1}$, (5) combined chemical nitrogen $(\mathrm{N})$, phosphorus (P), and potassium (K) (NPK) fertilizer at a rate of 150-40-20 kg N-P $\mathrm{O}_{5}-\mathrm{K}_{2} \mathrm{O} \mathrm{ha}^{-1}$, and (6) control. Cattle manure and PL were applied to provide $150 \mathrm{~kg} \mathrm{~N} \mathrm{ha}^{-1}$ assuming $65 \%$ availability in the first year of application. The nitrogen, phosphorus, and potassium content of CM and PL were analyzed each year to adjust application rate. Cattle manure and PL were spread between switchgrass rows in the first week of March. The sources of nitrogen, phosphorus, and potassium chemical fertilizers were urea $(46 \% \mathrm{~N})$, triple super phosphate $\left(46 \% \mathrm{P}_{2} \mathrm{O}_{5}\right)$ and potassium chloride $\left(60 \% \mathrm{~K}_{2} \mathrm{O}\right)$, respectively. About $1 / 3$ of the $\mathrm{N}$ and all $\mathrm{P}$ and $\mathrm{K}$ from chemical fertilizer sources were applied to each plot in the first week of April, and the remaining $2 / 3$ of the $\mathrm{N}$ was applied eight days after the first cut in June in both harvest frequencies. Crimson clover was seeded in the first week of April each year between switchgrass rows at recommended seed rate. In the establishment year, when switchgrass was at 3-4 leaf stage, broadleaf weeds were controlled with postemergence application of Quinclorac (3,7-Dichloro-8-quinolinecarboxylic acid) at $0.22 \mathrm{~kg}$ a.i. ha ${ }^{-1}$, dicamba $\left(0.27 \mathrm{~kg}\right.$ a.i. $\left.\mathrm{ha}^{-1}\right)$, and 2,4-D (2,4-Dichlorophenoxyacetic acid) at $0.78 \mathrm{~kg}$ a.i. ha ${ }^{-1}$ with $200 \mathrm{~L} \mathrm{ha}^{-1}$ water.

After two years of continuous treatment application in both sites, 10 composite soil samples were taken from each subplot using hand held soil auger from a depth of $0-10 \mathrm{~cm}$ when the soil was moist in the last week of November 2010 and 2011 from Perkins and LCB, respectively. The soil was first sieved to pass $8 \mathrm{~mm}$ sieve to remove roots and stones in the field. For each soil sample, the soil remaining between $8 \mathrm{~mm}$ and $4 \mathrm{~mm}$ sieves was air dried overnight at room temperature. Then, these soil samples were wet sieved to determine geometric mean diameter as a measure of water stable soil aggregates following modified Yoder method (Yoder 1936). In brief, the modified Yoder machine consists of two columns of five sieves with different mesh sizes $(4,2,1,0.5$, and $0.25 \mathrm{~mm}$ ) held together by a spring in each column. Fifty grams of air-dried soil sample were placed on the top sieve $(4 \mathrm{~mm})$. The column was slowly lowered into $15 \mathrm{~L}$ water-filled containers until the sample was submerged. Then, the samples were allowed to soak for $10 \mathrm{~min}$, followed by $10 \mathrm{~min}$ of agitation cycle where sieves were moved up and down at a rate of 30 cycles per minute. Finally, soil retained from each sieve was collected, dried, and weighed. The geometric mean diameter (GMD, mm) of water stable macro-aggregates were calculated using the following equation.

$$
\mathrm{GMD}=\exp \left[\left(\sum_{i}^{n} w i \log x i\right) /\left(\sum_{i}^{n} w i\right)\right]
$$

Where wi is the weight of aggregates in a given size class of a specific mean diameter xi. Similarly, aggregate size distribution (ASD) was calculated using the following equation.

$$
\operatorname{ASD}(\%)=[(\text { soil remaining in each individual sieve * 100)/(total weight of soil used })]
$$

\section{Statistical analysis}

Normality of data were tested with Shapiro-Wilk's W-test (Shapiro and Wilk 1965). All data were subjected to analysis of variance (ANOVA) using GLIMMIX procedure in SAS (SAS version 9.4, Cary, NC, USA). After preliminary statistical analysis showed a significant location effect, data were analyzed for each location. In this two-factor study, the focus was on the interaction effect of harvest frequency and nutrient source treatment levels rather than the main effects. Within GLIMMIX procedure, the "Slice" option under the LS means (least square means) statement was used to generate tests of simple effects (Winer, Brown, and Michels 1971) for nutrient source levels at each harvest sequence. The test produces an $\mathrm{F}$ value by extracting the appropriate rows from the coefficient matrix for the harvest frequency by nutrient source LS means (Schabenberger, Gregoire, and Kong 2000; Winer, Brown, and Michels 1971). Then, the "Lines" statement under LS means statement was used to generate a letter based pairwise LS means differences at $\mathrm{p}<0.1$ for each soil aggregate fraction. In addition, the effects of harvest frequency 
treatments on stable soil aggregates were briefly discussed for each location because their inclusion was warranted for comparison purpose.

\section{Results and discussion}

\section{Lake carl blackwell (LCB)}

The cumulative (8-2mm size class) water stable soil macro-aggregates at LCB for single harvest were $16 \%$ higher than twice harvest (Table 1). Our result from LCB is in agreement with several previous findings (Czarnes et al. 2000; Edaño 2013; Hütsch, Augustin, and Merbach 2002; Tisdall and Oades 1982). This higher percentage of soil aggregates for single harvest could be related to amount and continuous release of root exudates beside less soil disturbance due to traffic. For single harvest, there is continuous photosynthesis thus uninterrupted supply of root exudates to soil microbes (Czarnes et al. 2000). This could facilitate microbial activity and thus aggregate formation during organic matter mineralization that can serve as binding agent of soil particles. A different study on this same project indicated that one time harvest enhanced arbuscular mycorrhizal (AM) fungal colonization in switchgrass roots compared to twice harvest (Edaño 2013). The AM increases root surface area of switchgrass and can help in nutrient and moisture uptake and thus better biomass production with further increased root exudates. Hütsch, Augustin, and Merbach (2002) reviewed several studies on root exudate and reported that plants can release about $20 \%$ of carbon produced during photosynthesis as root exudates. The effect of root exudates such as mucilage and polygalacturonic acid as binding agent to form aggregates has been found effective (Tisdall and Oades 1982). Czarnes et al. (2000) reported that polygalacturonic acid may stabilize soil aggregates by increasing bond strength.

In addition, single harvest is associated with less machinery traffic, and this could have resulted in less soil compaction and disturbance. This could improve aggregate formation compared to twice harvesting. Jacobs et al. (2015) noted that total water infiltration rate was lower with 2-cut than 1-cut switchgrass. Similarly, the effect of single harvest at Perkins was significant for the soil aggregate size classes $(2-1 \mathrm{~mm}$ and $1-0.5 \mathrm{~mm})$.

The simple effect of different nutrient sources was statistically significant for the cumulative 8-2 mm fraction size class water stable soil macro-aggregates in both single- and twice-harvest frequencies (Table 2). Under single harvest, PL and CM increased water stable soil macro-aggregate to the extent of 32 and $24 \%$ over NPK fertilizer application, respectively (Table 2). Likewise, for aggregate fraction size between 2 and $8 \mathrm{~mm}$ and under single harvest, application of poultry litter and cattle manure had increased water stable soil macro-aggregates by 36.1 and $28.4 \%$ compared with inter-seeded crimson clover, respectively.

Table 1. Water stable soil macro-aggregates $\left(\mathrm{g} \mathrm{kg}^{-1}\right)$ by soil fraction size for twice- and single-harvest frequencies at Lake Carl Blackwell (LCB) and Perkins (when the two sites data combined), Oklahoma.

\begin{tabular}{|c|c|c|c|c|c|c|}
\hline \multirow[b]{2}{*}{ Harvest frequency } & \multicolumn{6}{|c|}{ Soil aggregate fraction size $(\mathrm{mm})$ and amount $\left(\mathrm{g} \mathrm{kg}^{-1}\right)$} \\
\hline & $8-4$ & $4-2$ & $2-1$ & $1-0.5$ & $0.5-0.25$ & $8-2$ \\
\hline & \multicolumn{6}{|c|}{ LCB } \\
\hline Single & 69 & $105 \mathrm{a}$ & 60 & 47 & 77 & $174 \mathrm{a}$ \\
\hline Twice & 61 & $89 \mathrm{~b}$ & 55 & 42 & 78 & $150 \mathrm{~b}$ \\
\hline Mean & 65 & 97 & 57 & 45 & 78 & 174 \\
\hline \multirow[t]{2}{*}{$P>F$} & 0.5018 & 0.0668 & 0.4020 & 0.2832 & 0.7114 & 0.0404 \\
\hline & \multicolumn{6}{|c|}{ Perkins } \\
\hline Single & 88 & 102 & $53 \mathrm{a}$ & $66 a$ & 199 & 190 \\
\hline Twice & 88 & 113 & $49 \mathrm{~b}$ & $52 \mathrm{~b}$ & 186 & 201 \\
\hline Mean & 88 & 107 & 51 & 59 & 192 & 196 \\
\hline$P>F$ & 0.9896 & 0.5004 & 0.0218 & 0.0232 & 0.5395 & 0.7653 \\
\hline
\end{tabular}

Means followed by different letter in a column for the same aggregate fraction size in a location are significantly different from each other at $p=0.1$. 
Table 2. Effect of nutrient sources on water stable soil macro-aggregates $\left(\mathrm{g} \mathrm{kg}^{-1}\right)$ under single and twice harvest for the different soil fraction size classes at Lake Carl Blackwell (LCB), Oklahoma.

\begin{tabular}{|c|c|c|c|c|c|c|}
\hline \multirow[b]{2}{*}{ Soil nutrient sources } & \multicolumn{6}{|c|}{ Soil aggregate fraction size $(\mathrm{mm})$ and amount $\left(\mathrm{g} \mathrm{kg}^{-1}\right)$} \\
\hline & $8-4$ & $4-2$ & $2-1$ & $1-0.5$ & $0.5-0.25$ & $8-2$ \\
\hline & \multicolumn{6}{|c|}{ Single harvest } \\
\hline Cattle manure & $87 \mathrm{ab}$ & 112 & $60 \mathrm{ab}$ & 43 & 74 & $199 a b$ \\
\hline Poultry litter & $106 a$ & 104 & $50 \mathrm{~b}$ & 43 & 88 & $211 \mathrm{a}$ \\
\hline Urea fertilizer & $56 \mathrm{bc}$ & 111 & $57 a b$ & 45 & 71 & $167 \mathrm{~b}$ \\
\hline NPK fertilizer & 61 bc & 99 & $52 \mathrm{~b}$ & 41 & 70 & $160 \mathrm{~b}$ \\
\hline Check & $44 \mathrm{C}$ & 107 & $71 \mathrm{a}$ & 54 & 85 & $151 \mathrm{~b}$ \\
\hline Inter-seeded clover & 56 bc & 98 & 70 a & 57 & 72 & $155 \mathrm{~b}$ \\
\hline \multirow[t]{2}{*}{ Simple effect $P>F$} & 0.0731 & 0.8655 & 0.0189 & 0.139 & 0.2391 & 0.0848 \\
\hline & \multicolumn{6}{|c|}{ Twice harvest } \\
\hline Cattle manure & $82 \mathrm{a}$ & 81 & $58 \mathrm{ab}$ & 45 & $79 a b$ & $163 a b$ \\
\hline Poultry litter & $96 a$ & 104 & $40 \mathrm{~b}$ & 31 & $64 \mathrm{~b}$ & $199 \mathrm{a}$ \\
\hline Urea fertilizer & $38 \mathrm{~b}$ & 90 & $54 a b$ & 43 & $84 a b$ & $128 \mathrm{~b}$ \\
\hline NPK fertilizer & $61 \mathrm{ab}$ & 81 & $55 \mathrm{ab}$ & 44 & $84 \mathrm{ab}$ & $142 \mathrm{~b}$ \\
\hline Check & $37 \mathrm{~b}$ & 87 & $71 \mathrm{a}$ & 53 & $95 \mathrm{a}$ & $124 \mathrm{~b}$ \\
\hline Inter-seeded clover & $50 \mathrm{~b}$ & 93 & $51 \mathrm{ab}$ & 37 & $64 \mathrm{~b}$ & $143 \mathrm{~b}$ \\
\hline Simple effect $P>F$ & 0.0796 & 0.5009 & 0.00876 & 0.3520 & 0.0106 & 0.0398 \\
\hline
\end{tabular}

Means followed by common letter in a column for the same aggregate fraction size and harvesting time are not significantly different from each other at $p=0.1$.

Under twice harvest, the effect of poultry litter and cattle manure application in increasing water stable soil macro-aggregates was substantial compared with other nutrient sources. For instance, application of PL increased the cumulative $(8-2 \mathrm{~mm})$ soil aggregates by $47.4 \%$ over NPK fertilizer application (Table 2). Further, under two harvest system, compared to crimson clover, poultry liter and cattle manure resulted in 39.2 and $13.9 \%$ more water stable soil macro-aggregates, respectively.

For both harvest frequencies, for the largest fraction size (8-4), water stable soil macro-aggregates were highest in cattle manure and poultry litter applied treatments. For the 2-1 fraction size class, under both harvest frequencies, water stable soil macro-aggregates were lowest for poultry litter plots. Inconsistent with any of the aggregate fraction sizes, the 2-1 fraction size class had the highest stable soil aggregates in the check plot. Similarly, for $0.5-0.25$ size class, a different response to nutrient sources was observed for twice harvest where the check had greater water stable soil macroaggregates than either poultry litter or inter-seeded crimson clover treatments (Table 2). This needs further investigation.

In contrast to chemical fertilizer, recycling of animal waste (poultry litter and cattle manure) can provide carbon as energy source benefiting the soil microbes. This additional benefit as energy source will increase soil microbial number, diversity, and activity ( $\mathrm{Tu}$ et al. 2006). The increased microbial activity produced different intermediate products that can serve as binding agent thus contributing to increased soil aggregate formation. Similar study showed that the total microbial biomass was significantly greater for animal waste treatments compared to chemical fertilizer application ( $\mathrm{Tu}$ et al. 2006). It has been indicated that when microbes decompose organic matter in the soil, they produce polysaccharides that serve as a binding agent to form soil macro-aggregates (Jastrow 1996). Another study indicated that humic substances produced through mineralization of added animal waste can improve soil macro-aggregate stability (Mazurak, Chesnin, and Thueel 1977; Ouessar, Hartmann, and De Smet 1993; Piccolo, Pietramellara, and Mbagwu 1997). The formation of these soil macro-aggregates can promote formation of continuous and big pores in the soil and thus will contribute to enhance water infiltration, recharge ground water and minimize runoff, and decrease sedimentation of dams and nutrient losses (Abu-Hamdeh, Abo-Qudais, and Othman 2006). Particularly, the possibility to increase soil moisture storage through more infiltration is important in this dry-land farming areas where moisture is one of the major limiting factors for biomass production. Soil crusting is another major problem for seed germination in this particular experimental site. Therefore, animal waste as nutrient source for switchgrass enhances stable soil 
aggregate formation that can in turn help in minimizing soil crusting problem through improved soil structure. Pagliai, Vignozzi, and Pellegrini (2004) noted that the addition of organic materials improved soil aggregates that played an important role in preventing soil crust formation.

\section{Perkins}

At Perkins, single harvest resulted in more water stable soil aggregate formation for the soil aggregate fraction size 2-1 $\mathrm{mm}$ and $1-0.5 \mathrm{~mm}$ than twice harvest (Table 1). However, the cumulative 8-2 $\mathrm{mm}$ size class for single harvest was numerically lower $\left(190 \mathrm{~g} \mathrm{~kg}^{-1}\right)$ than twice harvest $(201 \mathrm{~g}$ $\mathrm{kg}^{-1}$ ) (Table 1), but they were statistically in the same group. This absence of significant difference is in contrary to the results we found at LCB. This could be due to initial difference in soil organic carbon and clay content of these sites. The clay $\left(60 \mathrm{~g} \mathrm{~kg}^{-1}\right)$ and soil organic matter $\left(13 \mathrm{~g} \mathrm{~kg}^{-1}\right)$ contents of Perkins are significantly lower than LCB as indicated in the site description. Generally, soil with low clay and organic matter content has less microbial activity and thus could have less enhanced aggregate formation compared with soil with higher clay and organic matter content. In addition, the lower clay content at Perkins compared to LCB means reduced compaction effect due to machineries thus probably less effect of twice harvest on soil disturbance with regard to compaction and aggregate formation. This entails the complex nature of soil macro-aggregate formation and dependence on many interrelated factors. Soil aggregate formation is mediated by soil organic carbon, clay, carbonates, biota, ionic bridging, and their interaction that can be synergistic or disruptive to soil aggregate formation (Bronick and Lal 2005).

We recorded more cumulative above ground biomass yield at Perkins compared to LCB (Mohammed et al. 2015). This increased cumulative biomass from twice harvest at Perkins could also mean more carbon (energy source) to soil microbes through root exudates. This is particularly significant in soil with low initial soil organic carbon content like Perkins compared to LCB. This increased root excaudate from twice harvesting could have increased the number, diversity, and activity of soil microbes, thus improving aggregate formation compared to single harvest. In this connection, AM fungal hyphae important for soil structural improvement was tightly correlated with soil aggregate formation (Wilson et al. 2009). These can possibly explain why twice harvest produced numerically more water stable soil macroaggregates than single harvest at Perkins in contrast to LCB. Twice harvest can provide feed for animals and feedstock for biofuel thus diversifying the use of switchgrass biomass. The results at Perkins revealed that twice harvest enhanced above-ground biomass production, improve soil microbial activity, and eventually increased soil aggregate formation. The improvement in soil structure together with increased cumulative biomass could mean twice harvest is more preferable and presumably more sustainable than single harvest for this part of the State.

The simple effects of nutrient sources were also significant $(\mathrm{p}<0.1)$ for the $8-4$ and $4-2$ fraction size classes under single harvest; and 8-4, 4-2, 1-0.5, and 8-2 mm fraction size classes under twice harvest frequency (Table 3). Under single harvest, for the 4-2 size fraction, animal waste (mean of cattle manure and poultry litter) and inter-seeded crimson clover treatments had 131.7 and 169.2\% more water stable soil macro-aggregates than the NPK fertilizer treatment, respectively. This revealed the importance of organic fertilization in soil structural improvement compared with chemical fertilizer application.

Similarly, under twice harvest and the 8-4 fraction size class, animal waste (mean of poultry litter and cattle manure) had $116 \mathrm{~g} \mathrm{~kg}^{-1}$ more water stable soil macro-aggregates than NPK fertilizer application (Table 3). The simple effect of nutrient sources under twice harvest was significant for the cumulative $8-2 \mathrm{~mm}$ size class (Table 3). Under twice harvest, application of animal waste (mean of poultry litter and cattle manure) increased stable soil macro-aggregates by $153.6 \%$ over NPK chemical fertilizer application (Table 3). These results at Perkins conformed to our findings at LCB that animal wastes could increase water stable soil macro-aggregates by a large magnitude in both harvest systems. In a five-year field experiment, Celik, Ortas, and Kilic (2004) found that water stable aggregates were $65 \%$ greater with the application of manure. This 
Table 3. Effect of nutrient sources on water stable soil macro-aggregates $\left(\mathrm{g} \mathrm{kg}^{-1}\right)$ under single and twice harvest for the different soil fraction size classes at Perkins, Oklahoma.

\begin{tabular}{|c|c|c|c|c|c|c|}
\hline \multirow[b]{2}{*}{ Soil nutrient sources } & \multicolumn{6}{|c|}{ Soil aggregate fraction size $(\mathrm{mm})$ and amount $\left(\mathrm{g} \mathrm{kg}^{-1}\right)$} \\
\hline & $8-4$ & $4-2$ & $2-1$ & $1-0.5$ & $0.5-0.25$ & $8-2$ \\
\hline & \multicolumn{6}{|c|}{ Sinqle harvest } \\
\hline Cattle manure & $117 \mathrm{a}$ & $124 \mathrm{a}$ & 55 & 69 & 222 & 241 \\
\hline Poultry litter & $108 \mathrm{a}$ & $117 \mathrm{a}$ & 51 & 71 & 211 & 225 \\
\hline Urea fertilizer & $87 \mathrm{a}$ & $104 \mathrm{ab}$ & 56 & 75 & 156 & 191 \\
\hline NPK fertilizer & $61 \mathrm{ab}$ & $52 \mathrm{~b}$ & 51 & 55 & 183 & 113 \\
\hline Check & $53 \mathrm{~b}$ & $72 \mathrm{~b}$ & 49 & 58 & 222 & 125 \\
\hline Inter-seeded clover & $103 \mathrm{a}$ & $140 \mathrm{a}$ & 58 & 66 & 195 & 243 \\
\hline \multirow[t]{2}{*}{ Simple effect $P>F$} & 0.0751 & 0.1000 & 0.4812 & 0.8369 & 0.7148 & 0.4754 \\
\hline & \multicolumn{6}{|c|}{ Twice harvest } \\
\hline Cattle manure & $120 \mathrm{ab}$ & $145 \mathrm{a}$ & 39 & $87 \mathrm{a}$ & 160 & $265 \mathrm{a}$ \\
\hline Poultry litter & $160 \mathrm{a}$ & $138 a$ & 40 & $41 \mathrm{~b}$ & 185 & $298 a$ \\
\hline Urea fertilizer & $77 \mathrm{~b}$ & $131 \mathrm{a}$ & 42 & $45 \mathrm{~b}$ & 198 & $208 a b$ \\
\hline NPK fertilizer & $24 \mathrm{c}$ & $87 \mathrm{ab}$ & 48 & $53 \mathrm{ab}$ & 218 & $111 \mathrm{~b}$ \\
\hline Check & $133 a b$ & $128 \mathrm{a}$ & 55 & $53 \mathrm{ab}$ & 195 & $261 \mathrm{a}$ \\
\hline Inter-seeded clover & $13 \mathrm{c}$ & $49 \mathrm{~b}$ & 69 & $30 \mathrm{~b}$ & 162 & $62 \mathrm{~b}$ \\
\hline Simple effect $P>F$ & 0.1000 & 0.0506 & 0.3610 & 0.049 & 0.5762 & 0.0489 \\
\hline
\end{tabular}

Means followed by common letter in a column for the same aggregate fraction size and harvesting time are not significantly different from each other at $p=0.1$.

same study showed that soil water holding capacity increased by 85 and $56 \%$ with the application of compost and manure compared to the control, respectively, (Celik, Ortas, and Kilic 2004). Wortmann and Shapiro (2008) reported 200\% increase of large macro-aggregates $(>2 \mathrm{~mm})$ in both manure and compost applications within 15 days of application. Our results support these findings and Haynes and Naidu's comprehensive review report on soil structural improvement as influenced by different soil nutrient management practices (Haynes and Naidu 1998). The increase in water stable soil macro-aggregates due to application of cattle manure and poultry litter compared to NPK chemical fertilizer application could improve water infiltration. This will further help in increasing soil moisture storage in the profile with reduced surface runoff and nutrient and sediment accumulation into dams.

At Perkins and for inter-seeded crimson clover, a contrasting result was documented for the singleand twice-harvest frequencies where water stable soil macro-aggregates were increased under single harvest but reduced under twice-harvest system. The authors attribute this difference in water stable soil macro-aggregates in the inter-seeded crimson clover to harvest traffic that might have interfered with the growth of crimson clover in twice harvest system, consequently reducing its contribution to water stable soil macro-aggregate formation. However, additional research is needed to verify this assertion.

\section{Conclusion}

Single harvest at LCB increased the formation of water stable soil macro-aggregates for the cumulative $8-2 \mathrm{~mm}$ size class, but this result was not recorded at Perkins. This variation could be attributed to initial difference in soil organic matter and clay content of the two sites. This demonstrated the complex nature of soil macro-aggregate formation. Application of animal wastes (cattle manure and poultry litter) produced more water stable soil macro-aggregates mainly for the cumulative 8-2 mm aggregate fraction classes compared to NPK chemical fertilizer application to the extent of $47 \%$. The contribution of animal waste in increasing aggregate formation was substantial in soil with low initial soil organic matter content. Therefore, appropriate application of these animal wastes in switchgrass production field could lead to improved soil structure and an opportunity for safe disposal. Eventually, this could lead to a win-win situation to confined animal farming operation, cellulosic feedstock production and soil structural improvement. However, long-term monitoring of these practices is needed to evaluate system sustainability and profitability. 


\section{References}

Abu-Hamdeh, N. H., S. A. Abo-Qudais, and A. M. Othman. 2006. Effect of soil aggregate size on infiltration and erosion characteristics. European Journal of Soil Science 57:609-16. doi:10.1111/j.1365-2389.2005.00743.x.

Amezketa, E. 1999. Soil aggregate stability: A review. Journal of Sustainable Agriculture 14:83-151.

Bot, A., and J. Benites. 2005. The importance of soil organic matter: Key to drought-resistant soil and sustained food production. Rome, Italy: Food \& Agriculture Organization (FAo).

Britton, J., and G. L. Bullard. 1998. Summary of poultry litter samples in Oklahoma. Stillwater, OK: Oklahoma Cooperative Extension Fact Sheet CR-8214.

Bronick, C. J., and R. Lal. 2005. Soil structure and management: A review. Geoderma 124:3-22.

Celik, I., I. Ortas, and S. Kilic. 2004. Effects of compost, mycorrhiza, manure and fertilizer on some physical properties of a Chromoxerert soil. Soil and Tillage Research 78:59-67.

Czarnes, S., P. D. Hallett, A. G. Bengough, and I. M. Young. 2000. Root- and microbial-derived mucilages affect soil structure and water transport. European Journal of Soil Science 51:435-43. doi:10.1046/j.1365-2389.2000.00327.x.

Edaño, M. L. S. 2013. Effects of nutrient sources, harvest frequency, and environmental conditions on switchgrass production and soil properties. Stillwater, OK: Dissertation, Oklahoma State University.

Haynes, R., and R. Naidu. 1998. Influence of lime, fertilizer and manure applications on soil organic matter content and soil physical conditions: A review. Nutrient Cycling in Agroecosystems 51:123-37.

Hütsch, B. W., J. Augustin, and W. Merbach. 2002. Plant rhizodeposition: An important source for carbon turnover in soils. Journal of Plant Nutrition and Soil Science 165:397-407.

Jacobs, A., K. R. Brye, R. King, J. Douglas, L. S. Wood, L. C. Purcell, et al. 2015. Switchgrass management practice effects on near-surface soil properties in West-Central Arkansas. Open Journal of Soil Science 5:69.

Jastrow, J. 1996. Soil aggregate formation and the accrual of particulate and mineral-associated organic matter. Soil Biology and Biochemistry 28:665-76.

Jung, J. Y., R. Lal, J. D. Jastrow, and D. D. Tyler. 2011. Nitrogenous fertilizer effects on soil structural properties under switchgrass. Agriculture, Ecosystems \& Environment 141:215-20.

Kim, S. Y., P. Pramanik, P. L. E. Bodelier, and P. J. Kim. 2014. Cattle manure enhances methanogens miversity and methane emissions compared to swine manure under rice paddy. PLoS ONE 9:e113593. doi:10.1371/journal. pone.0113593.

Lee, D., V. Owens, and J. Doolittle. 2007. Switchgrass and soil carbon sequestration response to ammonium nitrate, manure, and harvest frequency on conservation reserve program land. Agronomy Journal 99:462-68.

Mazurak, A., L. Chesnin, and A. A. Thueel. 1977. Effects of beef cattle manure on water-stability of soil aggregates. Soil Science Society of America Journal 41:613-15.

Miller, R., and J. Jastrow. 1990. Hierarchy of root and mycorrhizal fungal interactions with soil aggregation. Soil Biology and Biochemistry 22:579-84.

Mohammed, Y. A., and K. G. Desta. 2017. Nutrient source affected quality biomass production of early harvest switchgrass for animal feed. Int. J. Agric. Environ. Res. 03:2455-6939.

Mohammed, Y. A., W. Raun, G. Kakani, H. Zhang, R. Taylor, K. G. Desta, et al. 2015. Nutrient sources and harvesting frequency on quality biomass production of switchgrass (Panicum virgatum L.). For Biofuel. Biomass Bioenergy. $81: 242-48$.

Moore, P., and D. Edwards. 2005. Long-term effects of poultry litter, alum-treated litter, and ammonium nitrate on aluminum availability in soils. Journal of Environmental Quality 34:2104-11.

Muir, J. P., M. A. Sanderson, W. R. Ocumpaugh, R. M. Jones, and R. L. Reed. 2001. Biomass production of ‘Alamo'switchgrass in response to nitrogen, phosphorus, and row spacing. Agronomy Journal 93:896-901.

Ouessar, M., R. Hartmann, and J. De Smet. 1993. Modification of the aggregate stability indices for the wet sieving method and the water drop technique. Soil Technology 6:329-36.

Pagliai, M., N. Vignozzi, and S. Pellegrini. 2004. Soil structure and the effect of management practices. Soil and Tillage Research 79:131-43.

Payne, J., and H. Zhang. 2011. Poultry litter nutrient management: A guide for producers and applicators. Stillwater, OK: Oklahoma Cooperative Extension Service, Division of Agricultural Sciences and Natural Resources, Oklahoma State University.

Piccolo, A., G. Pietramellara, and J. Mbagwu. 1997. Use of humic substances as soil conditioners to increase aggregate stability. Geoderma 75:267-77.

Sanderson, M. A., J. C. Read, and R. L. Reed. 1999. Harvest management of switchgrass for biomass feedstock and forage production. Agronomy Journal 91:5-10.

Schabenberger, O., T. G. Gregoire, and F. Kong. 2000. Collections of simple effects and their relationship to main effects and interactions in factorials. The American Statistician 54:210-14.

Seybold, C., and J. Herrick. 2001. Aggregate stability kit for soil quality assessments. Catena 44:37-45.

Shapiro, S. S., and M. B. Wilk. 1965. An analysis of variance test for normality (complete samples). Biometrika 52:591611. 
Six, J., K. Paustian, E. Elliott, and C. Combrink. 2000. Soil structure and organic matter I. Distribution of aggregatesize classes and aggregate-associated carbon. Soil Science Society of America Journal 64:681-89.

Stout, W., G. Jung, and J. Shaffer. 1988. Effects of soil and nitrogen on water use efficiency of tall fescue and switchgrass under humid conditions. Soil Science Society of America Journal 52:429-34.

Thomason, W., W. Raun, G. Johnson, C. Taliaferro, K. Freeman, K. Wynn, et al. 2005. Switchgrass response to harvest frequency and time and rate of applied nitrogen. Journal of Plant Nutrition 27:1199-226.

Tisdall, J., and J. Oades. 1980. The effect of crop rotation on aggregation in a red-brown earth. Soil Research 18:423-33.

Tisdall, J., and J. M. Oades. 1982. Organic matter and water-stable aggregates in soils. Journal of Soil Science 33:141-63.

Tu, C., F. J. Louws, N. G. Creamer, J. P. Mueller, C. Brownie, K. Fager, et al. 2006. Responses of soil microbial biomass and $\mathrm{N}$ availability to transition strategies from conventional to organic farming systems. Agriculture, Ecosystems \& Environment 113:206-15.

Wei, C., J. Ni, M. Gao, D. Xie, and S. Hasegawa. 2006. Anthropic pedogenesis of purple rock fragments in Sichuan Basin, China. Catena 68:51-58.

Wilson, G. W., C. W. Rice, M. C. Rillig, A. Springer, and D. C. Hartnett. 2009. Soil aggregation and carbon sequestration are tightly correlated with the abundance of arbuscular mycorrhizal fungi: Results from long-term field experiments. Ecology Letters 12:452-61.

Winer, B. J., D. R. Brown, and K. M. Michels. 1971. Statistical principles in experimental design. New York: McGrawHill.

Wortmann, C., and C. Shapiro. 2008. The effects of manure application on soil aggregation. Nutrient Cycling in Agroecosystems 80:173-80.

Yoder, R. E. 1936. A direct method of aggregate analysis of soils and a study of the physical nature of erosion losses. Agronomy Journal 28:337-51.

Zhen, Z., H. Liu, N. Wang, L. Guo, J. Meng, N. Ding, et al. 2014. Effects of manure compost application on soil microbial community diversity and soil microenvironments in a temperate cropland in China. PLoS ONE 9: e108555. doi:10.1371/journal.pone.0108555. 